\title{
Comparison of the effectiveness of acceptance and commitment therapy and cognitive behavior therapy on fatigue in multiple sclerosis (MS) patients
}

\author{
Mohsen Karimi ${ }^{1}$, Kaveh Qaderi Bagajan ${ }^{2}$ Zahra Naghsh $^{3}$, Tahereh Ghazaghi ${ }^{4}$, Lida Malekzadeh ${ }^{5}$ \\ 1. MSc of Clinical Psychology, Department of Clinical Psychology, Faculty of Medicine, Baqiyatallah University of Medical \\ Sciences, Tehran, Iran. ORCID ID: 0000-0001-9190-1442. \\ 2. Ph.D. of Psychology, Department of Clinical Psychology, Faculty of Psychology and Educational Sciences, Allameh \\ Tabataba'i University, Tehran, Iran. ORCID ID: 0000-0002-9606-9664. \\ 3. Assistant Professor, Department of Psychology, Faculty of Psychology and Educational Sciences, University of Tehran, \\ Tehran, Iran., (Corresponding Author), Tel: +98-9124396156, Email: z.naghsh@ut.ac.ir. ORCID ID: 0000-0001-6065-7838. \\ 4. Ph.D. student, Department of Psychology, Faculty of Psychology, International Tabriz-Aras University, Tabriz, Iran. \\ ORCID ID: 0000-0002-1810-7194. \\ 5. Ph.D. of Psychology, Department of Psychology, Faculty of Psychology and Educational Sciences, Tehran University, \\ Tehran, Iran. ORCID ID: 0000-0002-3839-0628.
}

\begin{abstract}
Background and Aim: Multiple sclerosis (MS) is a chronic progressive inflammatory disease of the central nervous system that patients suffer from its complications and experience physical and emotional side effects in their lifetime. The purpose of this study was to compare the effectiveness of acceptance and commitment therapy (ACT) and cognitive behavior therapy (CBT) on fatigue in MS patients.

Materials and Methods: This was a clinical trial with pre and post-test design. Among the patients with MS referring to the neurology department of Baqiyatallah Hospital, 30 patients were selected by convenient sampling method and randomly divided into two experimental and one control groups. Fatigue severity scale (FSS) was used to assess fatigue in the MS patients in the pre-treatment (pre-test) and post-treatment (post-test) stages.

Results: The results showed that ACT and CBT only with a little difference had similar effects on the improvement and decrease of severity of fatigue so that, we found a significant decrease in the scores of severity of fatigue in the post-test compared to the scores in the pretest.

Conclusion: The results indicated that ACT and CBT had the same effect on reducing the severity of fatigue in the MS patients.
\end{abstract}

Keywords: Acceptance and commitment therapy, Cognitive behavior therapy, Fatigue, Multiple sclerosis.

Received: Jan 23, 2020

Accepted: Jan 11, 2021

How to cite the article: Mohsen Karimi, Kaveh Qaderi Bagajan, Zahra Naghsh, Tahereh Ghazaghi, Lida Malekzadeh. Comparison of the effectiveness of acceptance and commitment therapy and cognitive behavior therapy on fatigue in multiple sclerosis (MS) patients.ÍĆSJKU 2021;26(4):117-131.

Copyright $@ 2018$ the Author (s). Published by Kurdistan University of Medical Sciences. This is an open access article distributed under the terms of the Creative Commons Attribution-Non Commercial License 4.0 (CCBYNC), where it is permissible to download, share, remix, transform, and buildup the work provided it is properly cited. The work cannot be used commercially without permission from the journal 


\section{مقايسه اثربخشى درمان مبتنى بر يذيرش و تعمد با درمان شناختى -رفتارى در بهبود

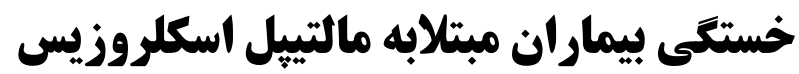

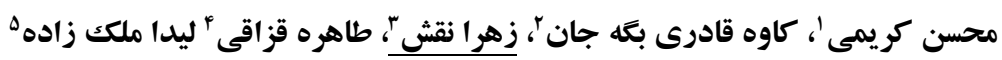

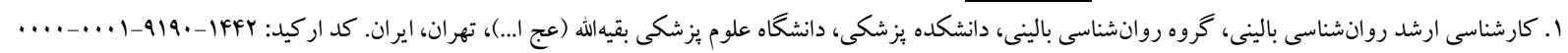

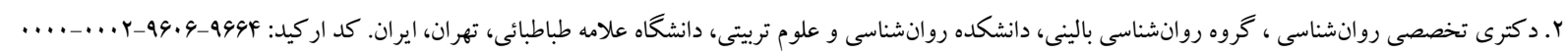

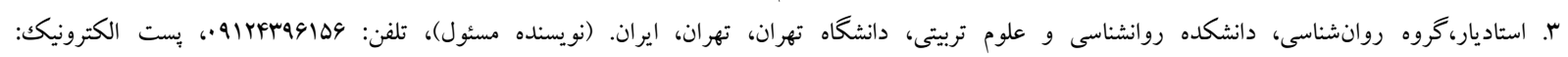

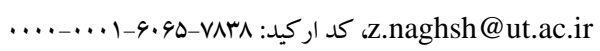

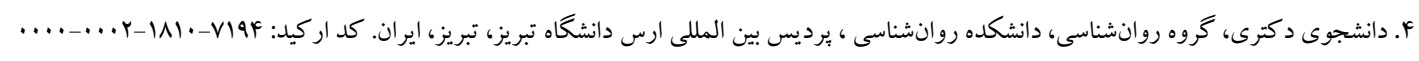

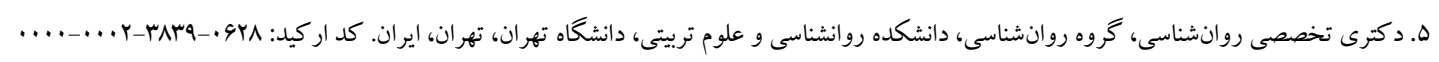

جكکטه

زمينه و هدف: مالتييل اسكلروزيس (ام.اس) يكك بيمارى مزمن، شايع و بيش رونده دستخاه عصبى است كـه افراد مبتلابه آن در

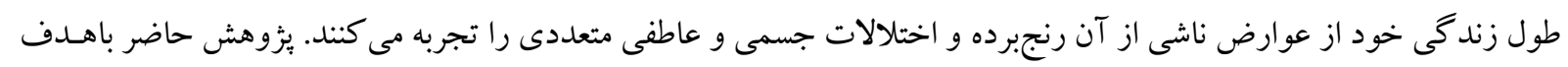

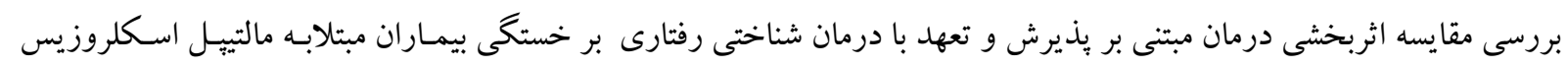
انجام كرفته است.

مواد و روشها: اين يُروهش در جهارجوب طرح كار آزمايى بالينى با يِيش آزمون و پس آزمون اجر اشده اسـت. از ميـان بيمـاران

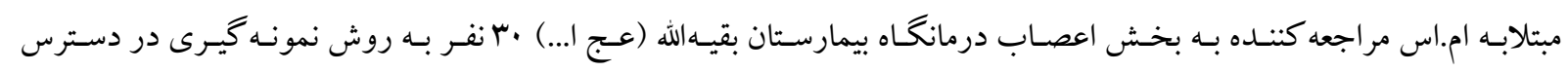

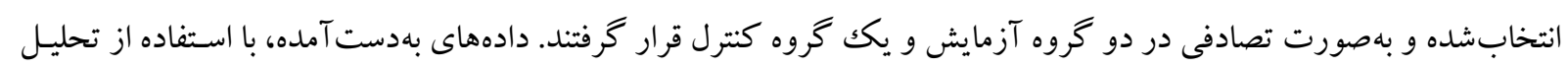

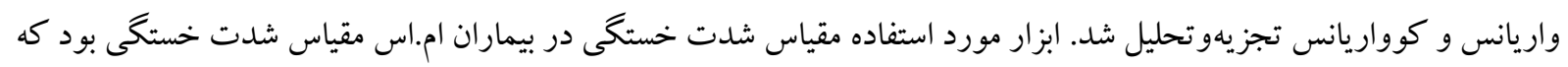

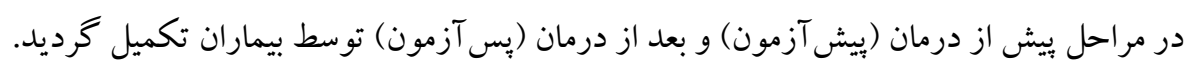

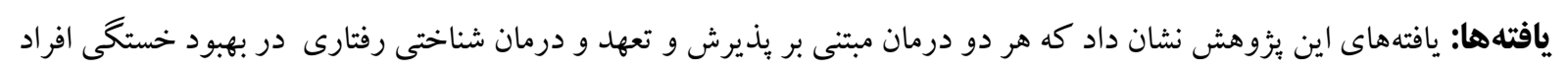

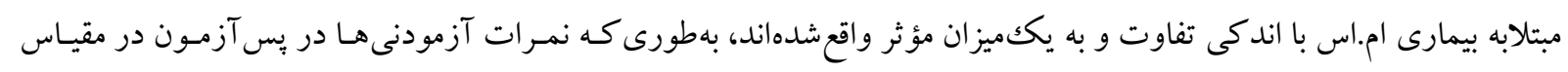
خستخى كاهش معنى دارى نسبت به نمرات بيش آزمون داشتند. نتيجه كيرى: نتايج يزوهش حاضر حاكى از آن است كه درمان مبتنى بر يذيرش و تعهد و درمان شناختى رفتارى به يكك اندازه

مى تواند در كاهش خستخى افراد مبتلابه ام.اس مؤثر باشد.

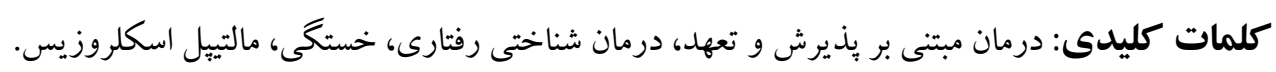

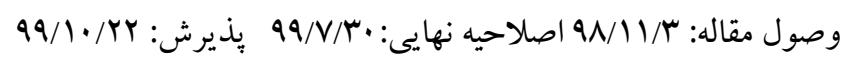


ازجمله نقص در سرعت فعاليتهاى ذهنى، انعطافيذيرى

شناختى و بازيابى اطلاعات اثراتى را اعمال مى كند (ها). برخى بيمارانى كه از خستخى رنج مىبرند شغل خود را از دست مىدهند، جراكه خستكى مانع از انجام وظايف و نقشهاى فردى و اجتماعى مى گردد و توانايى افراد را براى انجام كار و فعاليت و حفظ يكك زندكى طبيعى كاهش مى دهد(19) باينحال علىرغم وجود اثرات ناتوان كننده خستكى در بيمارى ام. اس متأسفانه اغلب در بيماران موردتوجه قرار نمى كيرد(IV). يكى از مداخلات انجامشده در مورد اين بيماران، درمان Cognitive Behavior Therapy, ) شناختى رفتارى (CBT بر اين مبناست كه خستخى فقط مرتبط با شدت و يا علائم بيمارى نيست بلكه تفسير و تعبيرهاى شناختى اين بيماران نيز برشدت احساس خستخى آنها مؤثر است( · (Y) مداخلات شناختى رفتارى در اصلاح باورها و رفتارهاى مرتبط با سلامت و همجينين در برطرف نمودن عوامل خطرساز بسيار مؤثر مىباشند. طبق مفروضات بنيادين درمان شناختى رفتارى نوع تفكر و ادراكى بيماران از واقع، هيجانها و رفتارهاى آنها را شكل مىدهد. مداخلات شناختى رفتارى آرون بكك بر اساس اتصال ضرورى اجزاى تفكر، احساس و رفتار يىريزى شده است(·r). در اين رويكرد درمانى بيمار تشويق مىشود تا رابطه بين افكارخودآيند منفى و حالات اضطرابى، افسردگى و و خستكى خود را بهعنوان مفروضاتى كه بايد به بوته آزمايش كذاشته شوند تلقى نموده و از رفتارهايى كه برآيند افكارخودآيند منفى است بهعنوان محكى براى ارزيابى و

$$
\text { اعتبار آن افكار بهره كيرد (Y). }
$$

در اين راستا، ئزوهشى كه باهدف بررسى تأثير درمان شناختى رفتارى در مقايسه با آموزش ريلكسيشن بر درمان خستخى بيماران ام.اس انجام شد، يافتها حاكى از آن بود كه گروه تحت درمان CBT كاهش معنادارى درشدت
ام.اس (Multiple Sclerosis, M.S) يكك بيمارى ميلين زداى سيسـتم عصـبى مركـزى اسـت( (1). در ايسن بيمـارى كه يكـى از شايعترين بيمارىهاى نورولوزيك در انسان است، بوشش ميلين (Myelin sheaths) سيستم عصسبى مركزى از قبيل مغز، عصب بينايى و نخـاع شـوكى دجّار آسيب مىشود(Y). اين بيمارى متداولترين بيمارى نورولوزيكك در ميان جوانان است كه اثرات ناتوان كنندهاى بر جاى مى گذارد(F,F) همجينين در زنان حدوداً دو برابر شايعتر از مردان است(ه,9). نتايج مطالعه جهانى بار

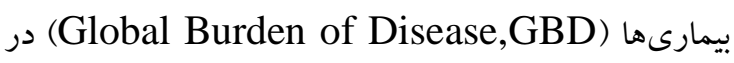
سال 19.r حاكى از آن است كه بيش از دو ميليون نفر در سراسر جهان به بيمارى ام.اس مبتلا هستند (V) در ايران نيز طبق آخرين دادههاى شيوع شناسى ميزان شيوع بيمارى ام.

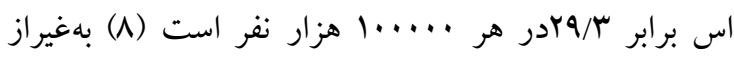
مسشكلات جسسمى ناشى از، از بـين رفـتن ميلـين سلولهاى عصبى اين بيمارى معمـولاً با مسشكلات

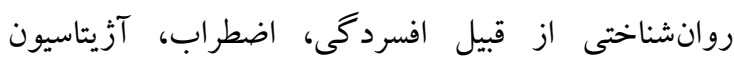

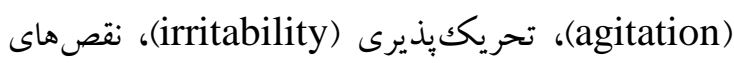
شناختى (obsession) (cognitive deficits)،وسواس) و ساير عوامل در افراد مبتلا همراه است(1)-9) با توجه به سنى كه بيمارى شروع مسىشود، بيمـاران مجبورند تا در برنامههاى زندگى، خانواده و كار تجديدنظر كرده و با عود بيمـارى و فقـدان خودمختـارى- كـه سـبب اضطراب و و

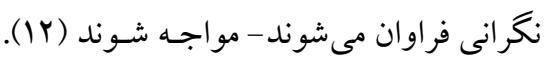

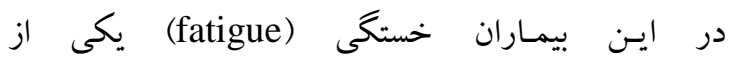
ناتوان كنندهترين علائسم است و با تخمينى بالاتر از س / • مىتوان كفت كه يكى از متداولترين نشانها در بيماران

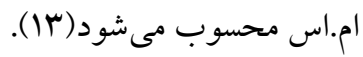
خستخى باعث ايجاد اختلال در كار، فعاليت اجتمـاعى و عملكرد روزانه بيماران مىشود(ه) و اثرات مخربى را بر بر كيفيت زندگى بيماران اعمال مى كند(IF) (I). خستكى علاوه بر كاركردهاى جسمانى، بر كاركردهاى شناختى بيماران 
ذهنى افزايش يابد. در قدم دوم، بر آكاهى روانى فرد در لحظه حال افزوده (Psychological Awareness) مىشود؛ در مرحله سوم به فرد آموخته مىشود كه خود را از اين تجارب ذهنى جدا سازد (جداسازى شناختى)

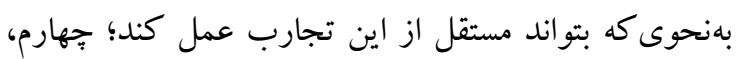
تلاش براى كاهش تمركز مفرط بر خود تجسمى يا داستان

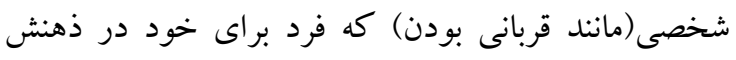

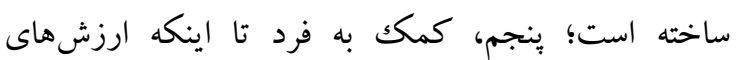
شخصى اصلى خود را بشناسد و بهطور واضح مشخص سازد

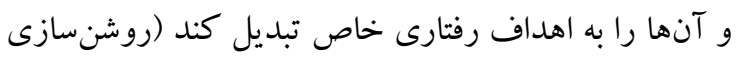
ارزشها). در نهايت، ايجاد انخيزه جهت عمل بهل متعهدانه، يعنى فعاليت معطوف به اهداف و و ارزشهاى مشخصشده(YV). روج(YN) طى ثُوهش خود مبنى بر اثربخشى درمان مبتى بر

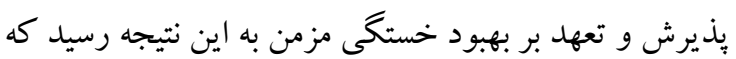

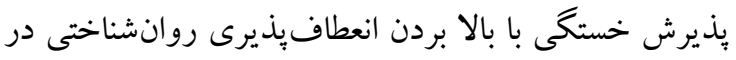

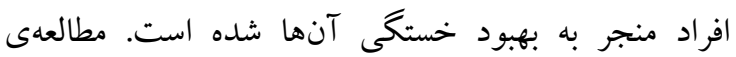
كاريغان و ديسج(؟) نيز نشان داد كه درمان مبتنى بر هذيرش و تعهد باعث كاهش خستكى و افزايش كيفيت

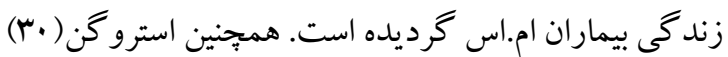
در يُوهش خود نشان داد كه درمان مبتنى بر بذيرش و تعهد

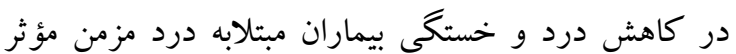

با توجه به يُشينه تحقيقاتى، از بين درمانهايى كه به صورت تكى بر بهبود خستخى بيماران ام.اس انجامشده است درمان مبتى بر يذيرش و تعهل و درمان شناختى رفتارى بيشترين

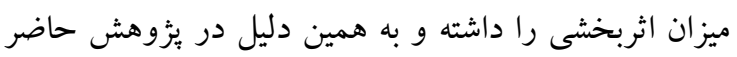

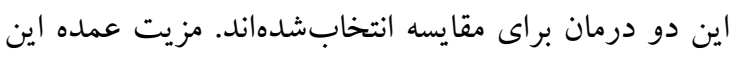

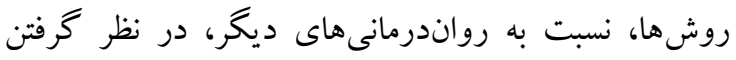

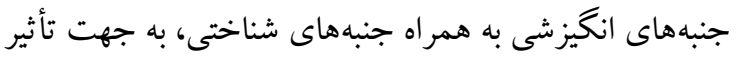

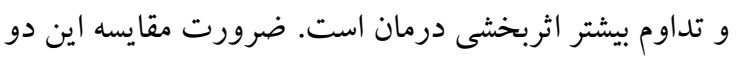
درمان ازاينجهت است كه تصوير واضحترى از درمانهاى نداى درمان
خستخى نسبت به گروه ريلكسيشن داشتند(YY). در مطالعهاى

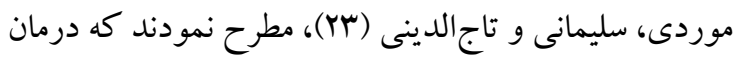

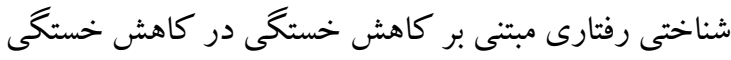
جسمانى، شناختى و اجتماعى بيماران مبتلابه ام.اس مؤثر مأر

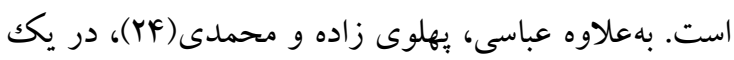
مطالعه كار آزمايى بالينى تصادفى به اين نتيجه دست يافتند

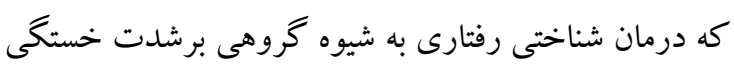

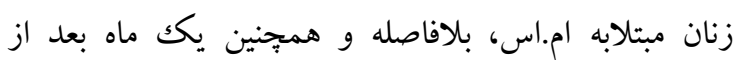
مداخله بهطور معنى دارى تأثير دارد. علاوه بر نسل دوم اين درمانهاى روانشناختى با عنوان

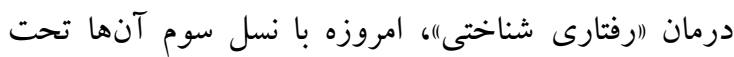
عنوان كلى مدلهاى مبتنى بر بذيرش ( Acceptanc based (Models آكاهى (Cognitive Therapy Based Mindfulness)، درمان فراشناختى (Metacognitive) و درمان مبتنى يذيرش و تعهد) Acceptance and Commitment Therapy ACT سعى مىشود تا ارتباط روانشناختى فرد با افكار و احساساتش افزايش يابد(YQ). درمان مبتنى بر بذيرش و تعهد

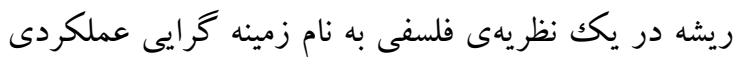
دارد و مبتنى بر يكك (Functional Contextualism) برنامه تحقيقاتى در مورد زبان و شناخت است كه نظريه جارجوب رابطههاى ذهنى (Rational Frame Theory) خوانده مىشود. شش فرايند مركزى درمان مبتى بر بذيرش و تعهد كه منجر به انعطافيذيرى روانشناختى مى شوند

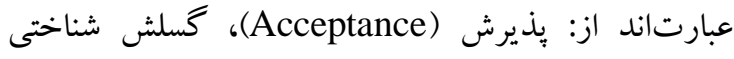
(Defusion)، خود بهعنوان زمينه (Self as Context)،

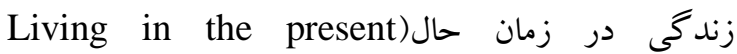
moment متعهدانه(Yc) (Committed Action) (كو). در اين درمان ابتدا سعى مىشود يذيرش روانى فرد در مورد تجارب (Psychological Acceptance) 
دييلم، عدم ابتلا به بيمارىهاى ديخر، توانيى شركت در

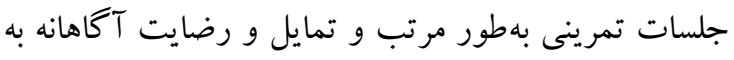

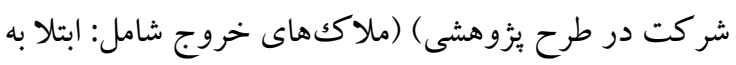

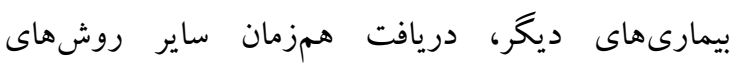

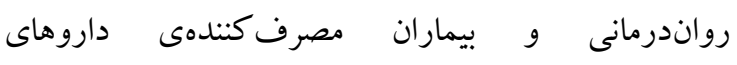
روانيزشكى) در هر گروه · انفر و در كل ·• نفر محاسبه

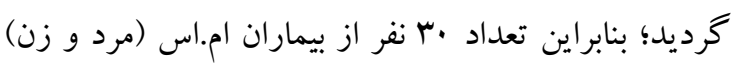
Fatigue Severity ) كه در مقياس شدت خستخ نمرهاى بالاتر از Scale, FSS متخصص اعصاب به شيوه در دسترس انتخابشده و در سه گروه (دو گروه درمان و يكك گروه شاهد) بهصورت

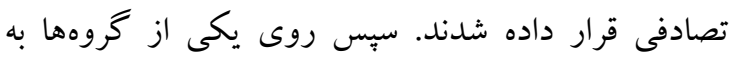

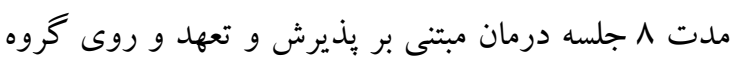

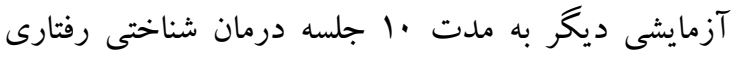

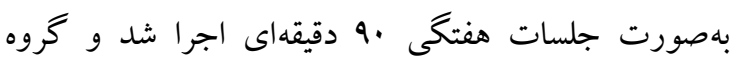

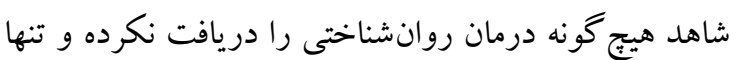
درمان دارويى معمول را دريافت كردند.

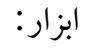
در اين يُزوهش از ابزارهاى ذيل استفاده گرديد.

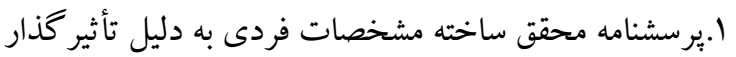
بودن عوامل زمينهاى بر حالات خلقى آزمودنىها تهيه شد.

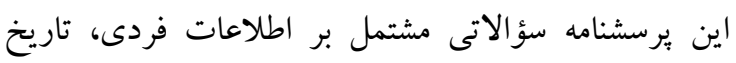
تولد، وضعيت تأهل و مدت بيمارى بود. FSS :FSS.r نام كروبٍ (Krupp) براى سنجش خستخى روانى در بيماران مبتلابه ام.اس ساخته شد. FSS را بهصورت كلى كلى و و با سرعت در اين بيماران مىسنجد. بهطورى كه نمره حاصل

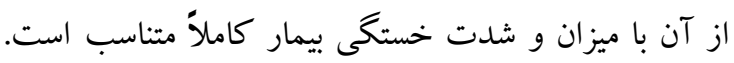
اين مقياس مشتمل بر 9 سؤال است. به هر سؤال برحسب مئس

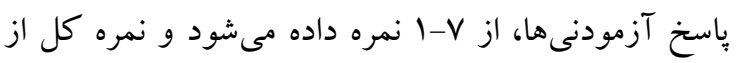

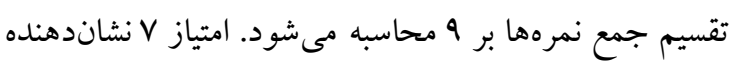
بالاترين حد خستخى و امتياز ا بيانگر فقدان خستخى است.
اثربخش اين حوزه به دست آيد تا درمانگران در انتخاب خط اول درمان روانشناختى و يا تركيب همزمان مداخلات

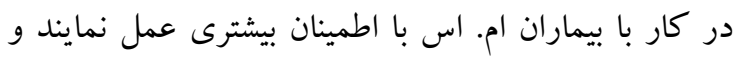

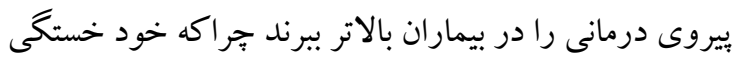

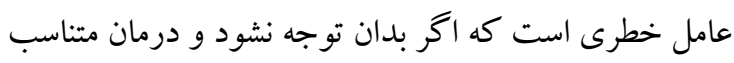

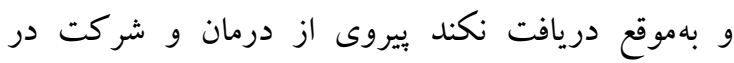
جلسات درمانى را با جالش اساسى روبهروى مى سازد. ازآنجا در هيج كدام از تحقيقات انجامشده تابهال در در كشور

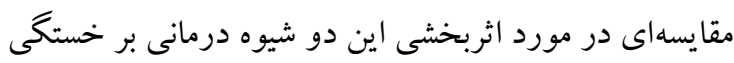

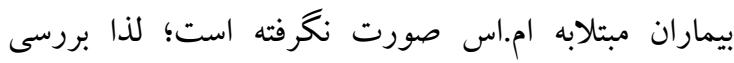
اثربخشى آنها بهصورت همزمان بر خستكى بيماران مبتلابه

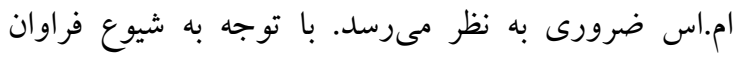

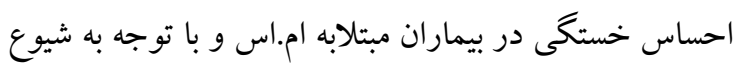
بيشتر بيمارى ام.اس در طى جند سال اخير در كل كشور

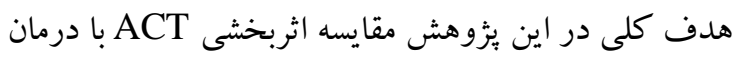
CBT گروه گواه است.

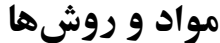

اين يُزوهش، در جارجوب طروح كار آزمايى بالينى با

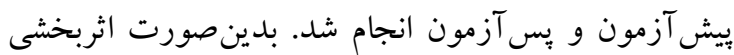
درمان شناختى - رفتارى و درمان مبتنى بر يذيرش و تعهد

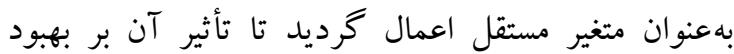
خستخى بيماران مبتلابه ام.اس بهعنوان متغير وابسته مشخص كردد. بِ از تائيد بُزوهش توسط كميته اخلاق دانشكاه

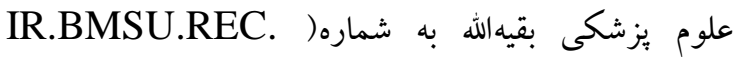

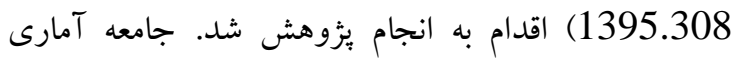
يُزوهش حاضر عبارت بودند از بيماران مبتلابه ام.اس كه لهان

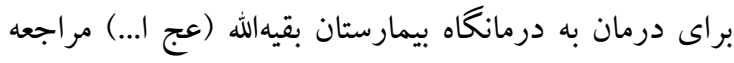

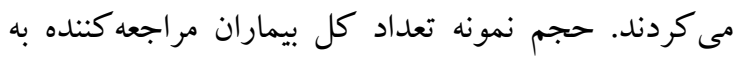
بخش اعصاب بيمارستان بقيهالله بود كه با در نظر داشتن

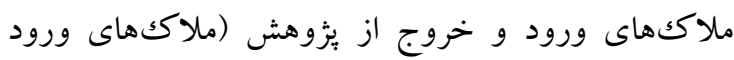

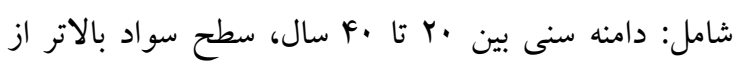


به دست آمد كه بيانغر ضريب بِايايى قابلقبول بِرسشنامه يادشده است. r. خلاصه يُروتكل درمان مبتنى بر بذيرش و تعهد بر اساس

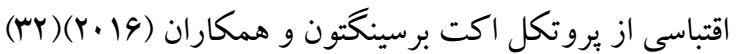
براى دردهاى مزمن باكمى تغييرات (جدول ()).
افراد با خستخى مرتبط با ام.اس تقريباً نمره //ه و افرادى كه

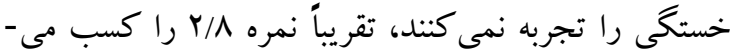

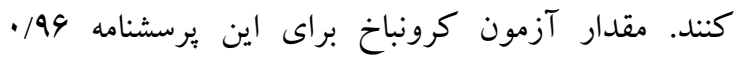
بهدست آمده كه حاكى از يايايى عالى اين ابزار است(آلم).

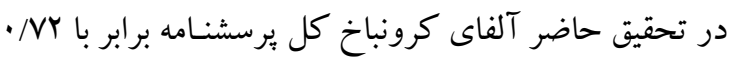

جدول 1. خلاصه يروتكل درمان مبتنى بر بذيرش و تعهد برسينتتون و همكاران (1 (r) براى دردهاى مز من باكمى تغييرات

اهداف جلسات درمان مبتنى بر بذيرش و تعهد

جلسات

آشنايى افراد با يكديكر و برقرارى رابطه درمانى؛ آشنا نمودن افراد با موضوع يثوهش؛ بررسى بيمارى ام.اس در هر يك از افراد

كروه اعم از مدت بيمارى و اقدامات انجامشده؛ سنجش كلى و سنجش شيوههاى كنترلى و ايجاد درماندگى خلاق و ياسخ به

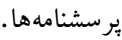

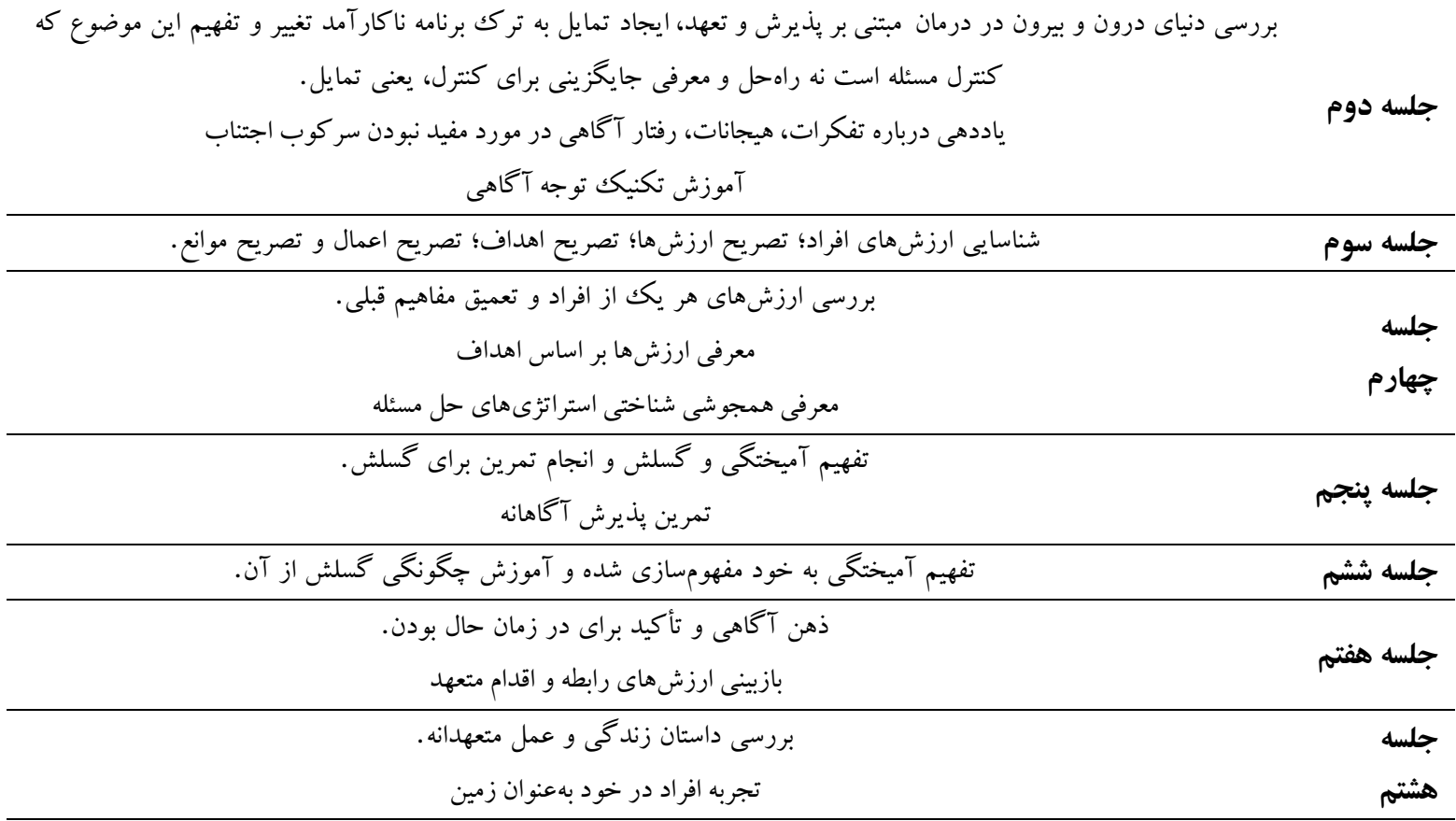

؟.بلاصه بروتكل درمان شناختى-رفتارى بر اساس اقتباسى از ساختار درمان شناختى رفتارى تطبيق دادهده براى خستكى

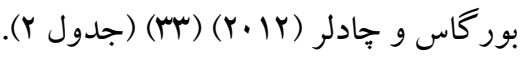

جدول r. خلاصه يروتكل درمان شناختى-رفتارى بر اساس اقتباسى از ساختار درمان شناختى رفتارى تطبيق دادهشده براى خستىى

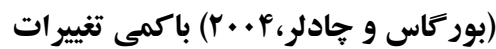

\begin{tabular}{|c|c|}
\hline اهداف جلسات درمان شناختى -رفتارى & جلسات \\
\hline درس اول :خوشامد گَيى، شرح دستور كار - گرفتن تاريخجهاى از مشكل خستخى بيمار - استنباط باورها و رفتارهاى مقابلهاى & \multirow{3}{*}{ جلسه اول } \\
\hline 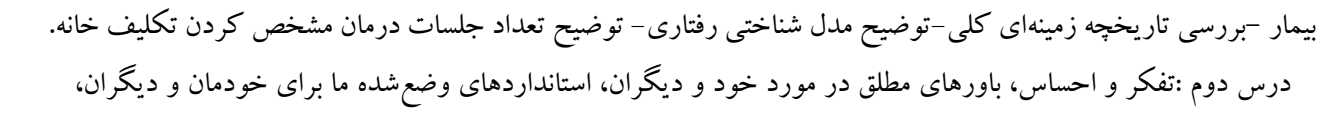 & \\
\hline تمثيل جمدان براى مراحل شناخت درمانى. & \\
\hline
\end{tabular}

هبلم علمى دانشكاه علوه بِزشكى كردستان / دوره بيست و شش / دعر و آبان م.ع| 
مرور مدل درمان شناختى -رفتارى و مرور منطق درمان-بررسى تاريخجه زمينهاى كلى جلسات

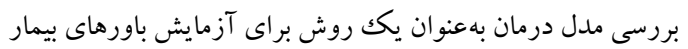

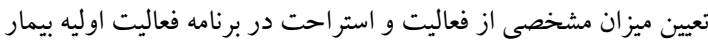

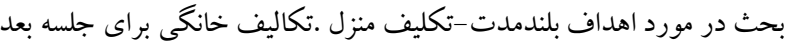

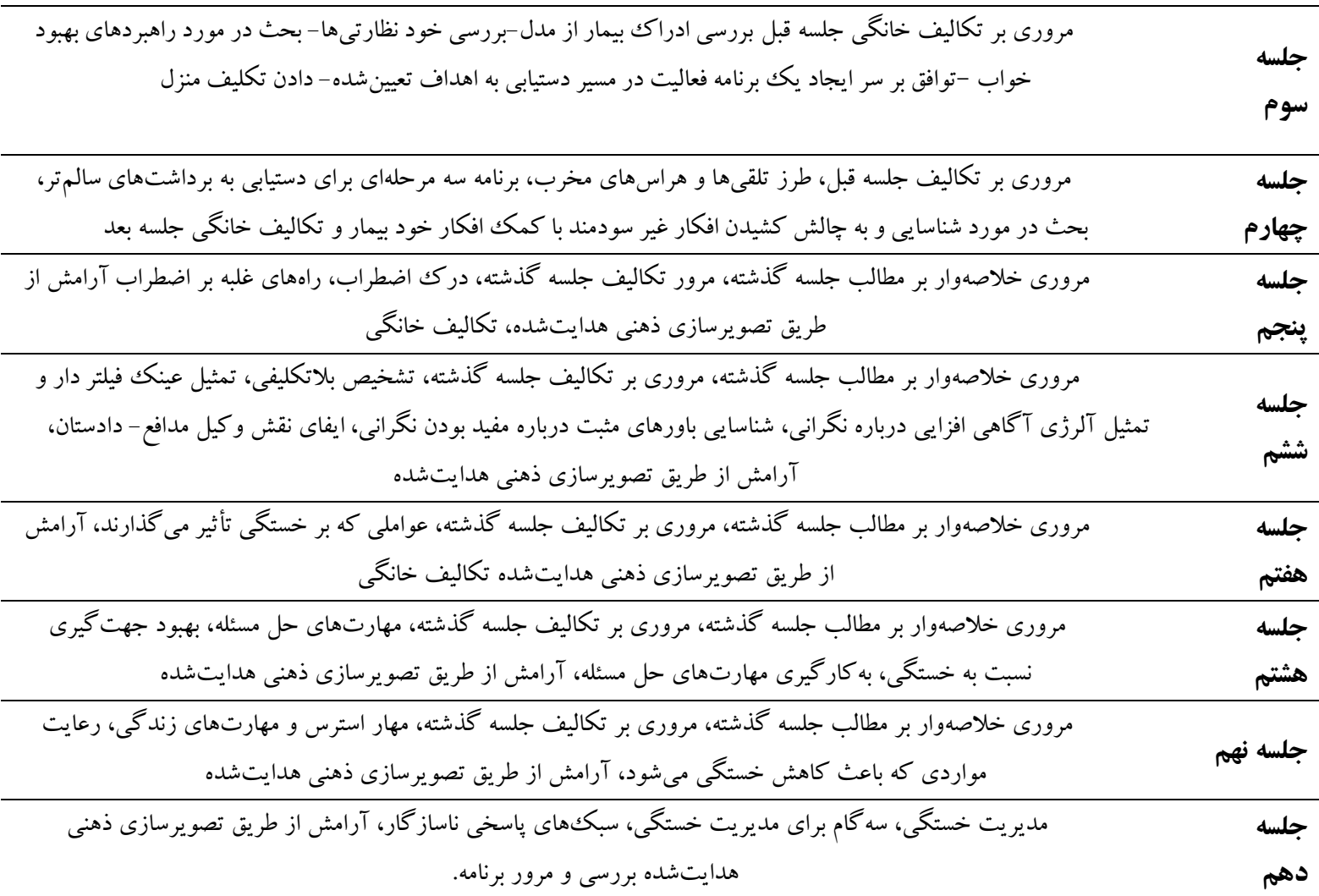

فراوانى را با حدود •/·ب درصد نمونه را به خـود اختصـاص داده اند. ميانگين و انحراف معيار سن به ترتيب گـروه روش

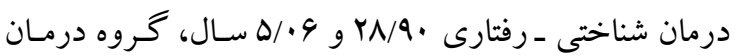

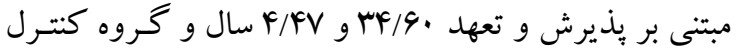

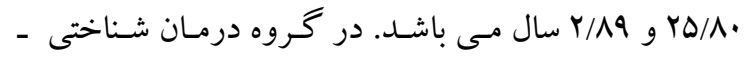
رفتارى، آزمودنى هاى مجرد حدود • ••ه درصد و آزمودنى

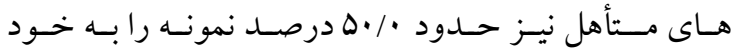
اختصاص داده، در گرووه درمان مبتنى بـر يـذيرش و تعهـد،

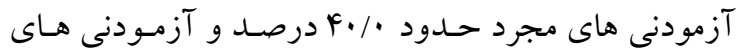

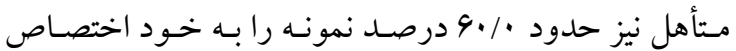
داده، و در گرووه كنترل، آزمودنى هـاى مجـرد حسدود •/ درصد و آزمودنى هاى مستأهل نيز حدود · • ب درصد نمونسه
همان طورى كه در جـدول ب ملاحظه مسى شـود، در گَروه

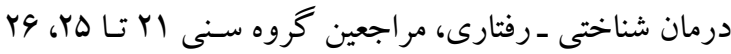
تا •r و اس تا هr سال هر كدام بيشترين فراوانى را بـا حسدود

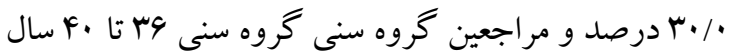
كمترين فراوانى را با حدود • • إدرصـد نمونسه را بـه خـود اختصاص داده، در گرووه درمان مبتنى بـر بــذيرش و تعهـد،

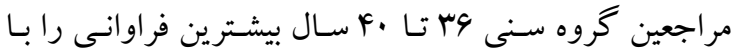

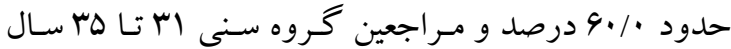
كمترين فراوانى را با حدود • • إدرصـد نمونسه را بـه خـود اختصاص داده، و در گروه كنترل، مراجعين گرووه سـنى

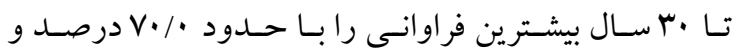
مـراجعين گ گروه سـنى كـروه سـنى اY تـا ها سـال كمتـرين 
مبتنى بر بذيرش و تعهد، مـر اجعين بـا مــدت بيمـارى Y تـا ب بيشترين فراوانى را با حدود • /•ه درصد و مراجعين با مـدت

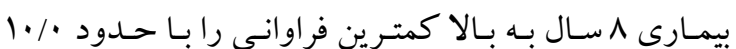
درصد نمونه را به خود اختصـاص داده، و در گحروه كنترل، مراجعين با مدت بيمارى ب تا ب بيشترين فراوانى را بـا حسدود

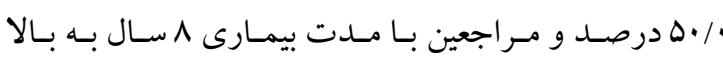
كمترين فراوانى را با حدود · • ا درصـد نمونسه را بـه خـود

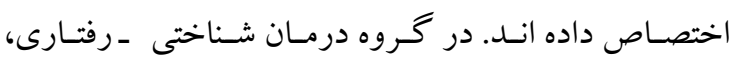

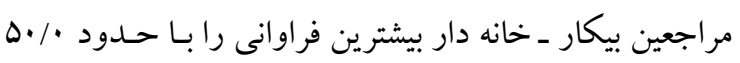
درصد و مراجعين داراى مشاغل آزاد كمترين فراوانى رابـا

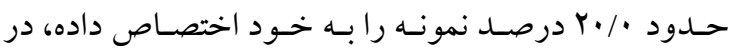
كروه درمان مبتنى بر بذيرش و تعهد، مراجعين بيكار ـ خانه دار و همجنين داراى مشاغل دولتى هـر كـدام حسدود • • درصد نمونه را به خود اختصـاص داده، و در گحروه كنترل، مراجعين بيكار ـ خانه دار بيشترين فراوانى را بـا حسدود • . درصد و مراجعين داراى مشاغل آزاد كمترين فراوانى رابـا حـدود • • ا درصـد نمونسه را بـه خـود اختصـاص داده انسد.
را به خود اختصـاص داده انـلـ. در گَروه درمـان شـناختى رفتارى، مراجعين با سطح تحصيلات فوق ديسيلم و ليسـانس بيشترين فراوانى را با حدود ·••• درصد و مراجعين با سـطح تحصيلات تا دييلم كمترين فراوانى را با حدود • • 1 درصـد نمونه را به خود اختصـاص داده، در گ گروه درمـان مبتنى بـر يذيرش و تعهد، مراجعين با سـطح تحصسيلات فـوق ديسيلم و ليسانس بيشترين فراوانى رابا حدود • •9 درصد و مراجعين با سطح تحصيلات تا دييلم و فوق ليسانس هر كدام كمترين فراوانى را با حدود ·• ·r درصد نمونه را به خـود اختصـاص داده، و در گرووه كنترل، مراجعين با سـطح تحصسيلات فوق دييلم و ليسانس بيشترين فراوانى را با حسدود • / م درصـد و مراجعين با سطح تحصيلات تا ديـيلم كمتـرين فراوانى رابـا حدود • • • درصد نمونه را به خـود اختصـاص داده انـد. در

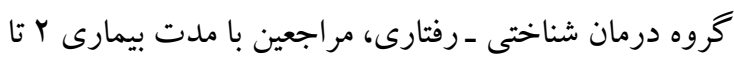
ب بيشترين فراوانسى را بـا حسدود · ••ه درصـد و مـراجعين بـا مدت بيمارى ^ سال به بالا كمترين فراوانى رابا حدود •/ 1. درصـد نمونـه را بـه خـود اختصـاص داده، در گـروه درمـان

جدول r. اطلاعات جمعيت شناختى كروههاى آزمايش و كنترل

\begin{tabular}{|c|c|c|c|c|c|c|c|c|}
\hline \multicolumn{8}{|c|}{ كروه } & \multirow{3}{*}{ 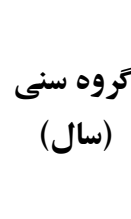 } \\
\hline \multicolumn{2}{|c|}{ كل } & \multicolumn{2}{|c|}{ كنترل } & \multicolumn{2}{|c|}{ درمان مبتنى بر يذيرش و } & \multicolumn{2}{|c|}{ درمان شناختى - رفتارى } & \\
\hline درصد & فراوانى & درصد & فراوانى & درصد & فراوانى & درصد & فراوانى & \\
\hline$r \cdot / \cdot$ & 9 & $r \cdot / \cdot$ & $r$ & . & . & $\mu \cdot / \cdot$ & $r$ & I I \\
\hline$\mu r / r$ & ir & $V \cdot / \cdot$ & $v$ & $\mu \cdot / \cdot$ & $r$ & $\mu \cdot / \cdot$ & $r$ & 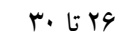 \\
\hline $\mid r / 4$ & f & . & . & $1 . \%$ & 1 & $\mu \cdot / \cdot$ & $r$ & اب تا هץ \\
\hline $1 r / r$ & v & . & . & $9.1 \cdot$ & 9 & $1 . \%$ & 1 & G. F F F \\
\hline $1 \cdots /$ & $r$. & $1 \cdots /$ & 1. & $1 \cdots /$ & 1. & $1 \cdots /$ & 1. & كل \\
\hline \multicolumn{9}{|c|}{ تأهل } \\
\hline$\Delta q / V$ & IV & $\Lambda \cdot / \cdot$ & $\wedge$ & $k \cdot /$ & F & $\Delta \cdot \%$ & $\Delta$ & مجرد \\
\hline$\kappa r / r$ & ir & $r \cdot / \cdot$ & $r$ & $9.1 \cdot$ & 9 & $0 . /$ & $\Delta$ & متأهل \\
\hline $1 \cdots /$ & $r$. & $1 \cdots /$ & 1. & $1 \cdot \cdot /$ & 1. & $1, \cdots /$ & 1. & كل \\
\hline \multicolumn{9}{|c|}{ تحصيلات } \\
\hline$r q / V$ & $\wedge$ & $r \cdot / \cdot$ & $r$ & $r \cdot / \cdot$ & r & $f \cdot / \cdot$ & f & تا دييلم \\
\hline
\end{tabular}


زمرا نقش

\begin{tabular}{|c|c|c|c|c|c|c|c|c|}
\hline $9 \pi / \pi$ & 19 & $\Lambda \cdot / \cdot$ & $\wedge$ & $9 \cdot 1 \cdot$ & 9 & $\Delta \cdot / \cdot$ & $\Delta$ & فوقدييلم و \\
\hline $1 . \%$ & $r$ & . & $\cdot$ & $r \cdot / \cdot$ & r & $1 \cdot 1$ & 1 & فوقليسانس \\
\hline $.01 . /$ & $r$. & $1 \cdots$ & 1. & $1 \cdots$ & 1. & $1 \cdots$ & 1. & كل \\
\hline \multicolumn{9}{|c|}{ مدت بيمارى } \\
\hline$r \cdot / \cdot$ & 4 & $r \cdot / \cdot$ & $r$ & $r \cdot / \cdot$ & $r$ & $r \cdot / \cdot$ & $r$ & تا ا سال \\
\hline $0 \cdot 1 \cdot$ & 10 & $\Delta \cdot /$ & $\Delta$ & $0 \cdot \%$ & $\Delta$ & $\Delta \cdot /$ & $\Delta$ & r \\
\hline$r \cdot / \cdot$ & 4 & $r \cdot / \cdot$ & $r$ & $r \cdot / \cdot$ & $r$ & $r \cdot / \cdot$ & $r$ & $V E$ \\
\hline $1 . \%$ & $r$ & $1 \%$ & 1 & $1 . \%$ & 1 & $1 \%$ & 1 & م سال به بالا \\
\hline $1 \cdots$ & $r$. & $1 \cdots$ & 1. & $1 \cdots$ & 1. & $1 \cdots$ & 1. & كل \\
\hline \multicolumn{9}{|c|}{ وضعيت اشتغال } \\
\hline$\Delta r / r$ & 19 & $9 \cdot 1 \cdot$ & 4 & $\Delta \cdot \%$ & $\Delta$ & $\Delta \cdot /$ & $\Delta$ & خيكار - خانهدار \\
\hline$r q / V$ & 11 & $\mu \cdot /$ & $r$ & $0 \cdot \%$ & $\theta$ & $r \cdot /$ & $r$ & مشاغل دولتى \\
\hline $1 . \%$ & $r$ & $1 \%$ & 1 & . & . & $r \cdot / \cdot$ & $r$ & مشاغل آزاد \\
\hline $1 \cdots /$ & $r$. & $1 \cdots$ & 1. & $1 \cdots$ & 1. & $1 \cdots$ & 1. & كل \\
\hline
\end{tabular}

\section{يافتهها}

يافتهاى توصيفى نمرات خستخى گروههاى آزمايش و كنترل در مراحل بيش آزمون، بِ آزمون و ييگيخى را نشان مىدهد (جدول F). سه ييشفرض تحليل كوواريانس حاكى

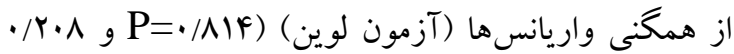
F= اسميرنف) (در سه گروه P=/r) و همخنى شيب رگرسيون يافتها در متغير خستخى بودند.

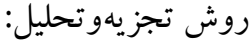
بهمنظور تجزيهوتحليل دادهها از روشهاى آمار توصيفى (محاسبه فراوانى، درصد، ميانگين، انحراف معيار)، آزمون لوين، آزمون كلمو گروف ـ اسميرنف، تحليل كوواريانس يكك متغيرى (آنكوا) و روش آلفاى كرونباخ جهت محاسبه ضريب وايايى استفادهده است. تجزيهوتحليل دادهها به كمك نرمافزار كامبيوترى SPSS نسخه بيست و جهارم صورت كرفت و ضمناً سطح معنىدارى در اين تحقيق، هاء

جدول †. ميانكين و انحر اف معيار نمرههاى خستىى كروههاى آزمايش و كنترل در مراحل ييش آزمون و پبس آزمون

\begin{tabular}{|c|c|c|c|c|}
\hline انحر اف معيار & ميانكين & ششاخص آمارى & 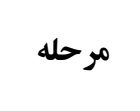 & متغير \\
\hline $9 / \Gamma \wedge$ & $4 \cdot / 4$ & درمان شناختى - رفتارى & \multirow{3}{*}{ بيش آزمون } & \multirow{6}{*}{ نستخى } \\
\hline V/A & $k \mu / 1$. & درمان مبتنى بر بذيرش و تعهد & & \\
\hline$\Lambda / \Delta 9$ & $r \cdot / v$ & كنترل ل & & \\
\hline$\Delta / r \Delta$ & $r r / r$ & درمان شناختى ـ رفتارى & \multirow{3}{*}{ ي بس آزمون } & \\
\hline$\Delta / 91$ & $r q / 4$ & درمان مبتنى بر بذيرش و تعهد & & \\
\hline $9 / \Delta \mathrm{V}$ & Rr/Q. & كنترل & & \\
\hline
\end{tabular}


در جدول ه هنتايج آزمون بررسى همخنى شيبهاى ت تعامل غير معنىدار است. بنابراين، مفروضه همخنى شيب

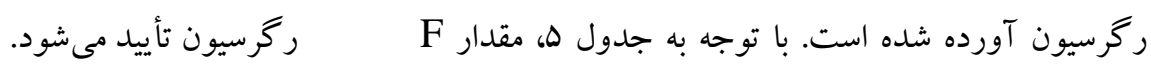

جدول ه. نتايج آزمون بررسى ييشفرض همتنى شيبهاى ركرسيون نمرات خستكى دو كروه در جامعه

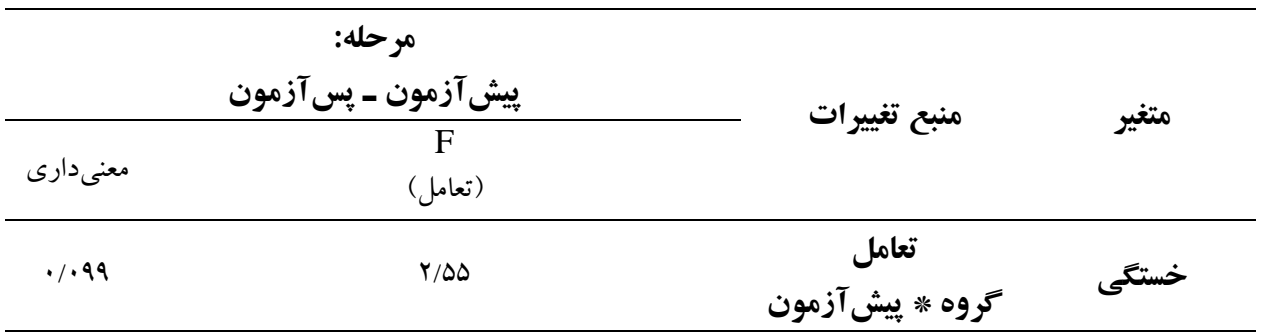

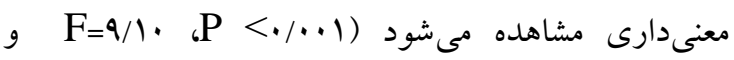
(df=1

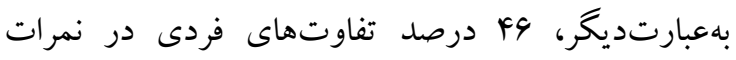

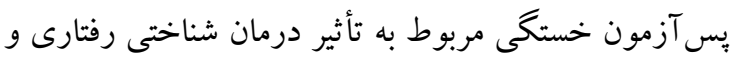

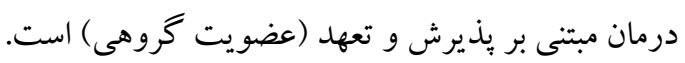

در راستاى آزمون فرضيه، نتايج تحليل كوواريانس يككراهه

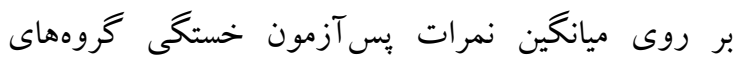

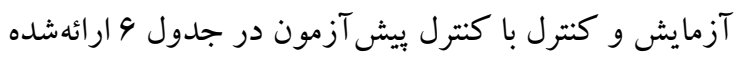
است. با توجه به جدول 9، با كنترل ويش بـ آزمون بين

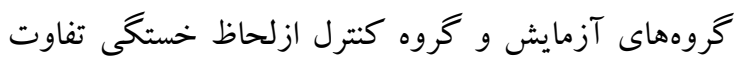

جدول 9. نتايج تحليل كوواريانس يككراهه ميانكين نمرات بس آزمون خستعى كروههاى آزمايش و كنترل با كتترل ييش آزمون

\begin{tabular}{|c|c|c|c|c|c|c|c|c|}
\hline توان & اتا & معنى سطارى & $\mathbf{F}$ & مجذانكين & آزادى درجه & مجموع مجذورات & تغييرات & 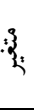 \\
\hline אוא/. &.$\mu$ &.$/ M$ & $r / r$. & FV/AT & 1 & FV/AY & ي ييش آزمون & \\
\hline.$/ 9 \Delta r$ & $\cdot / 49$ &.$/ . .1$ & $9 / 1$. & $14 r / .9$ & $r$ & r99/11 & كروه & \\
\hline & & & & $r \cdot / 11$ & $r$ & FYY/MV & خطا & \\
\hline
\end{tabular}

به ميانگين گروه كنترل ( • (F/D)، موجب كاهش خستخى

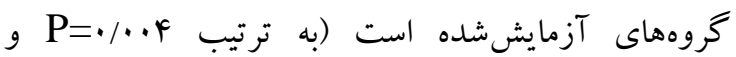

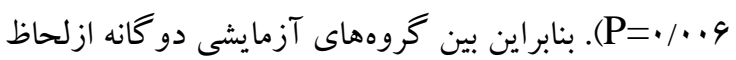
خستكى تفاوت معنىدارى وجود ندارد. اين امر بيانگر تأثير

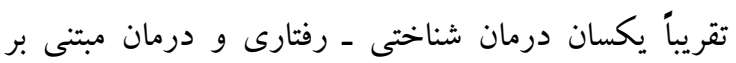
يذيرش و تعهد در كاهش خستخى است (جدول V V).
معنىدار شدن تفاوت بين گروهها با استفـاده از تحليل

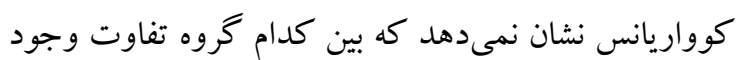
دارد لذا به دنبال اين تحليل، از تحليل تعقيبى بونفرونى

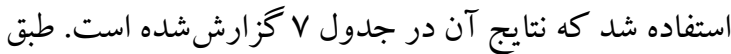
نتايج آن درمان مبتنى بر بذيرش و تعهد و درمان إندان شناختى

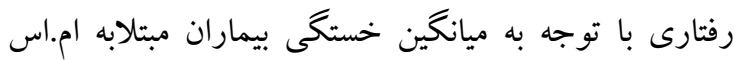

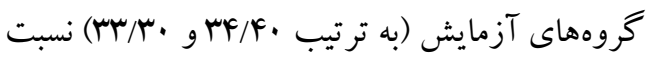


جدول ل. نتايج آزمـون تعقيب بونفرونى بين نمرات ميانكين پس آزمون خستغى كروههاى آزمايش و كنترل با كنترل پيش آزمون

\begin{tabular}{|c|c|c|c|c|c|}
\hline 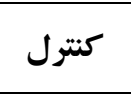 & 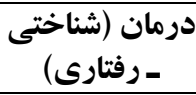 & 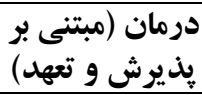 & ميانكين & كروهها & \\
\hline$(p=\cdot / \cdot \cdot q)$ & - & & $\pi / \mu$. & درمان شناختى - رفتارى (CBT) & 1 \\
\hline \multirow[t]{2}{*}{$(p=\cdot / \cdot f q)$} & & & $\mu F / F$. & درمان مبتنى بر بذيرش و تعهد (ACT) & $r$ \\
\hline & & & $\mathrm{kr} / \mathrm{Q}$. & كنترل & $r$ \\
\hline
\end{tabular}

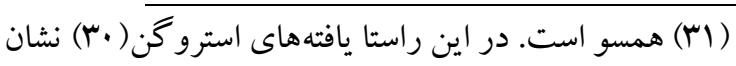

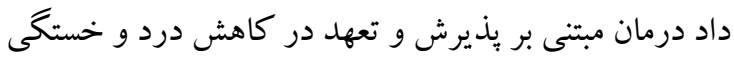
بيمـار ان مبتلابـه درد مـزمن مـؤثر اسـت. همجنــين مطالعـات

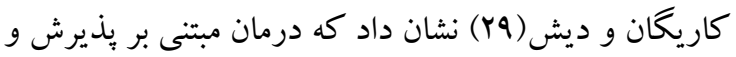
تعهلد در بهبود خستخى بيماران مبتلابه ام.اس اثربخش بوده و باعث كـاهش خستخى و افزايش كيفيـت زنـدكى در ايـن بيماران شده است. روج(YN) نيز طى ثزوهش خود مبنى براثر

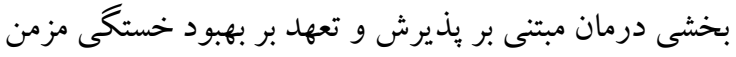

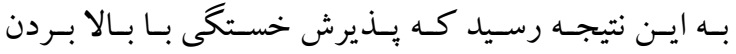
انعطاف يذيرى روانشناختى در افراد به بهبود خستخى آنهـا منجر گرديده و باعث بهبود خستخى در آنها شده است. در تبيين اين يافتها مى توان استـلال كرد كـه بـه كار خيرى

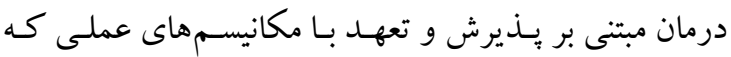

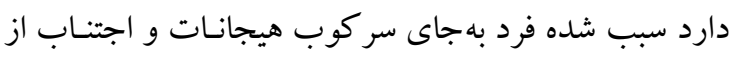

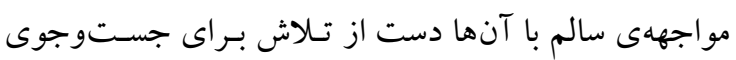

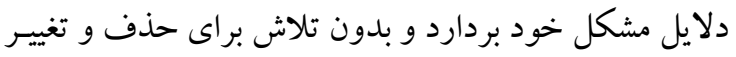
كه سـبب مزمن شـدن درد مىشـود هيجانـاتش را بيـذيرد و

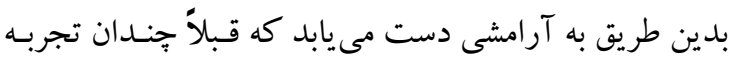

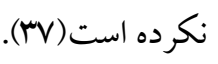

اما در خصوص تفاوتهاى اثربخشى اين درمانها در بيشـينه

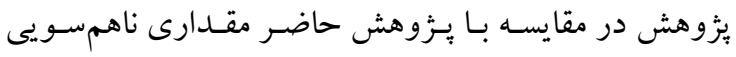

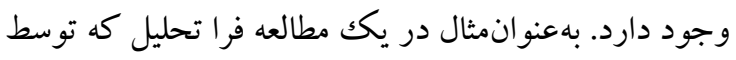

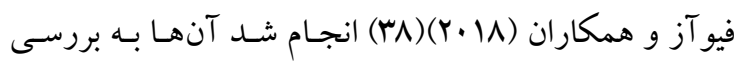

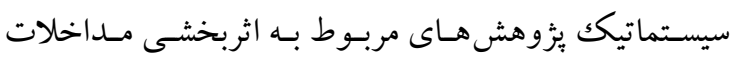

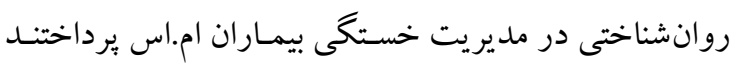
يزّوهش حاضر باهـدف مقايسـه اثربخشى درمـان مبتنى بـر

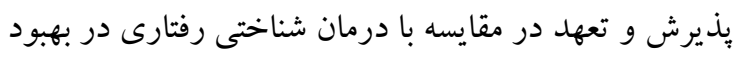

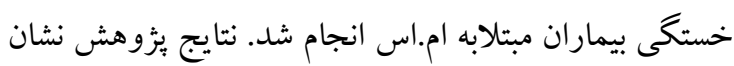
داد درمان مبتنى بر بذيرش و تعهد و درمان شناختى رفتارى

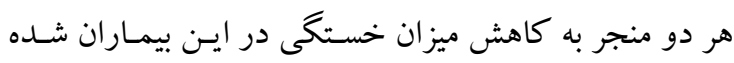

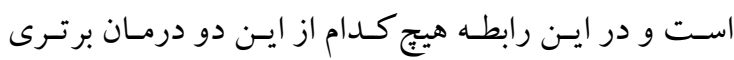

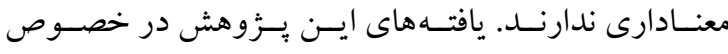
اثربخشى درمان شناختى رفتارى بر بهبود خستخى بيماران ام.

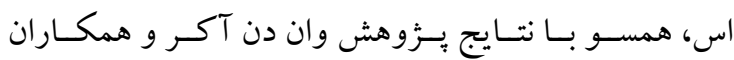

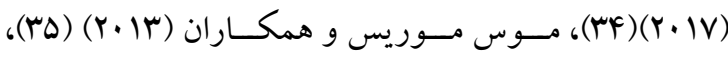

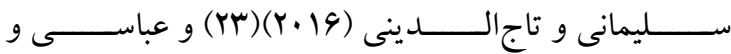

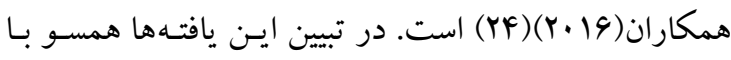
مدل نظرى بيشنهادشـده توسط ونكسل و مـوريس (4. (Y)

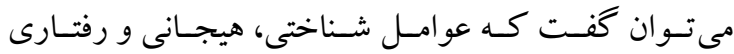

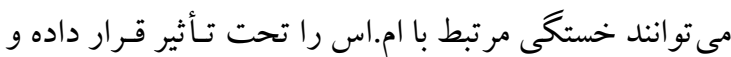

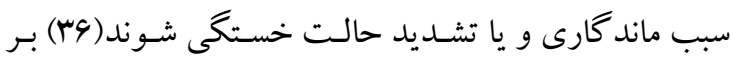
همين اساس هدف قرار دادن شناختهاى ناكار آمد مرتبط با

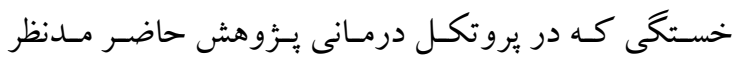

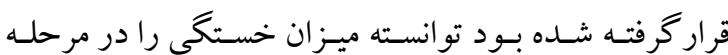
يُ إزمون كاهش دهد و اثرات درمانى اعمال كند.

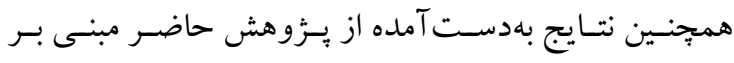

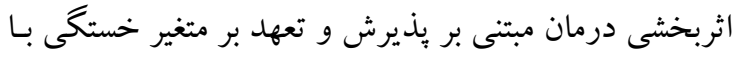

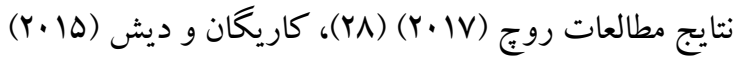

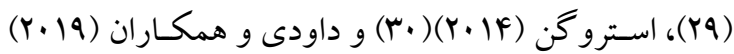




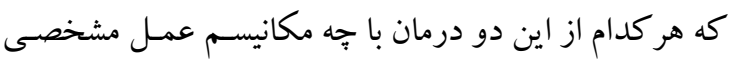

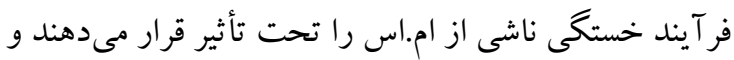

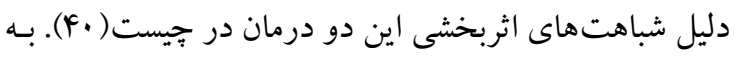
همين دليل بيشنهاد مى شود در مطالعات آتى به شكل فر آيند

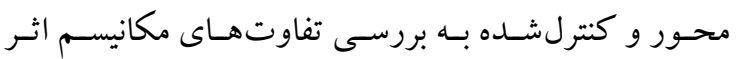

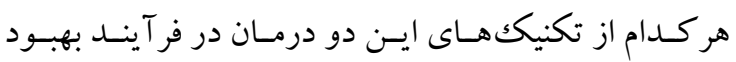
خستخى يرداخته شود.

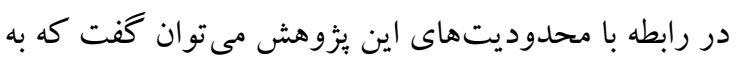

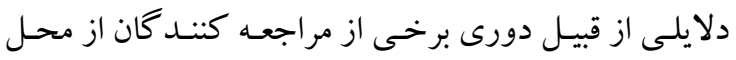
بركزارى جلسات درمان، محـدوديت هـاى جسـمانى و وعـدم تو انايى مالى در برخى موارد باعث كاهش كيفيت حضور در جلسات مى شد و به همين دليل هـم بايستى در تعميم نتـايج

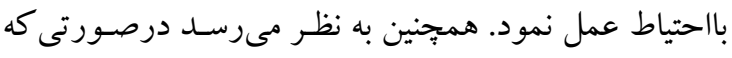

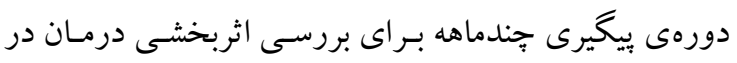

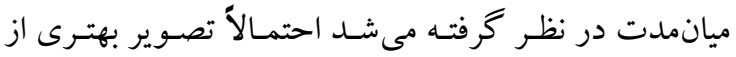
تفاوتهاى دو درمان در ميانمدت به دست مى آمـد كهـ بـهـ

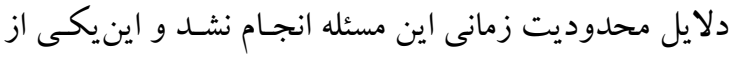
محدوديت هاى ناخواسته بُزوهش حاضر است كه لازم است در تبيين نتايج بدان توجه نمود.

\section{نتيجه كيرى}

نتايج يزوهش حاضر نشان داد كه مى توان مداخله هاى مبتنى بر درمان شناختى -رفتارى و درمان مبتنى بر يـذيرش و تعهـد را بهطور موفقيت آميزى بـراى كـاهش خستخى در بيمـاران مبتلابه ام.اس به كار گرفت و هيج كدام از اين دو درمـان در

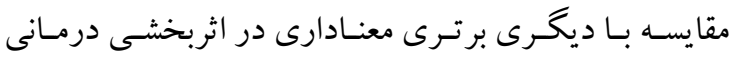
نداشتند؛ لذا هردو درمان مى تواند در زمينه ى كار بـالينى و مداخلات درمانى شواهد محور در زمينهى احساس خستخى

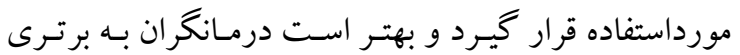
اثربخشى درمان شناختى رفتارى بر بهبود خستـى ناشى از

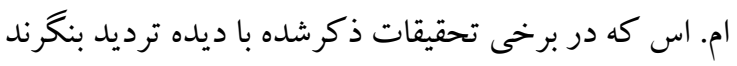
و مطالعات فرا تحليل وسيع ترى در اين زمينه موردنياز اسـت.
يافتهاى آنها حاكى از آن بود كه رواندرمانىها خطط اول

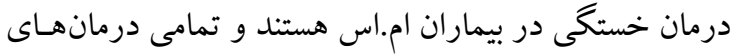

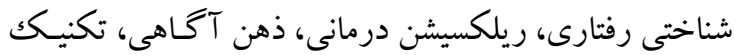
آرامسازى عضلانى و درمان متمر كز بر شناخت اجتماعى در

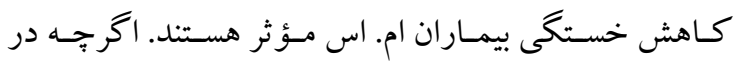

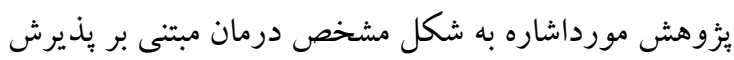

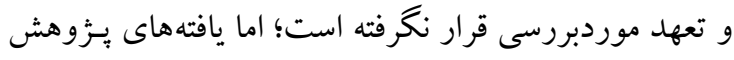

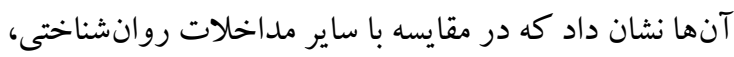

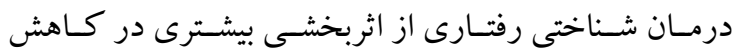

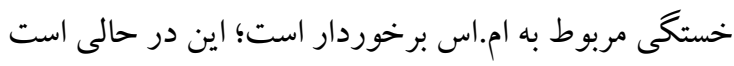

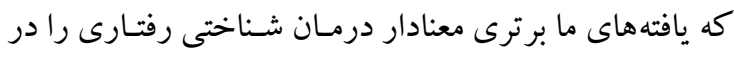
مقايسه با درمان مبتنى بر بذيرش و تعهـد نشـان نـداد؛ و ايـن

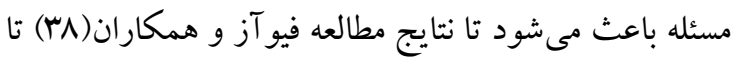
حدى با קـالش روبـهرو شـود جر اكسه برتـرى نسبى درمـان شناختى رفتارى زمانى كه با درمان مبتنى بر بـــيرش و تعهـد

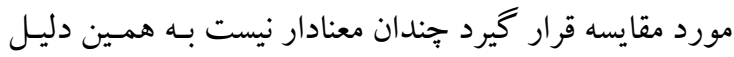

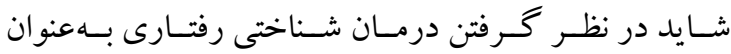

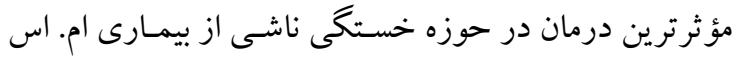
مقدارى عجولانه و فاقد وجاهت تجربى باشد بر همين اساس وييشـنهاد مى شـود در مطالعـات بعـدى بـهويزه مطالعـات فـرا تحليل يُزوهشهايى كه اثربخشى درمان مبتنى بـر يـذيرش و

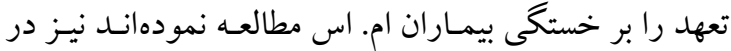

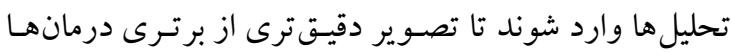

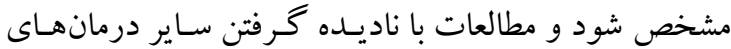

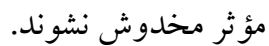

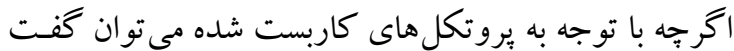

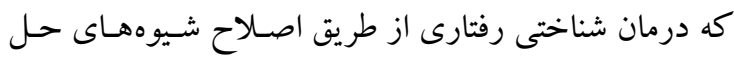

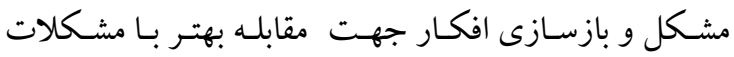

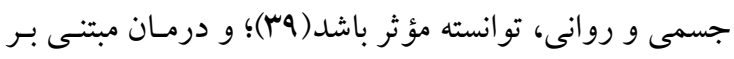

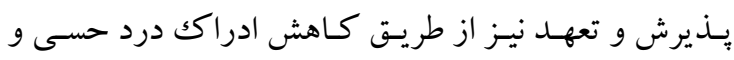

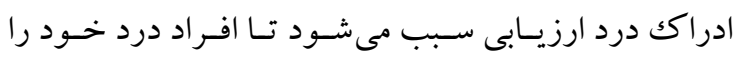

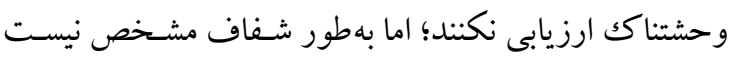




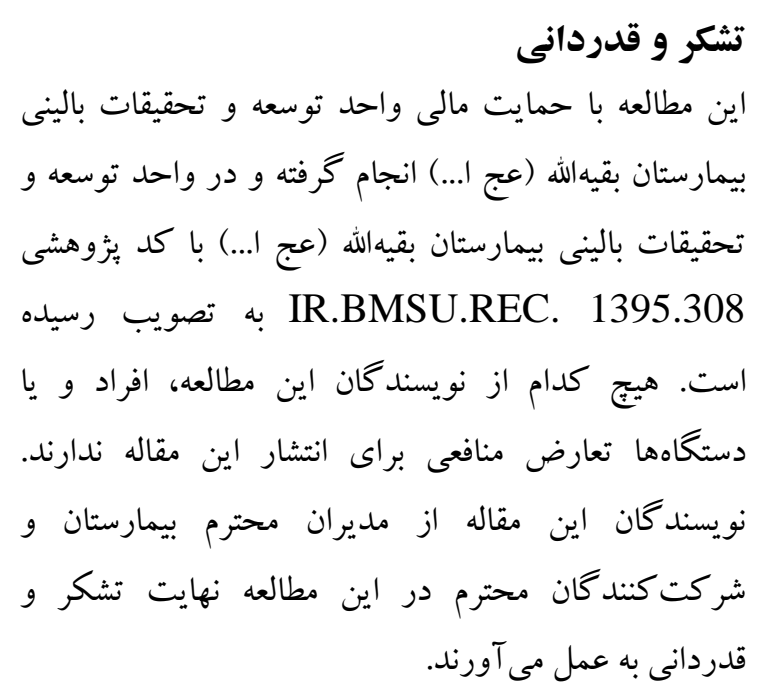

$$
\begin{aligned}
& \text { نهايتاً مى توان استدلال كرد كـه درمـان شـناختى -رفتـارى و }
\end{aligned}
$$

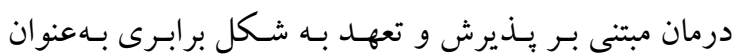

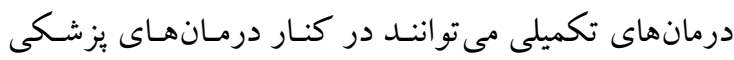

$$
\begin{aligned}
& \text { منجر به ارتقاء كيفيت درمان كردد. }
\end{aligned}
$$

\section{منابع}

1. Alroughani R, Inshasi JS, Deleu D, Al-Hashel J, Shakra M, Elalamy OR, et al. An Overview of High-Efficacy Drugs for Multiple Sclerosis: Gulf Region Expert Opinion. Neurol Ther. 2019;8(1):13-23.

2. Kenner M, Menon U, Elliott DG. Multiple sclerosis as a painful disease. Int Rev Neurobiol. 2007;79:303-321.

3. Brownlee WJ, Hardy TA, Fazekas F, Miller DH. Diagnosis of multiple sclerosis: progress and challenges. Lancet. 2017;389:1336-1346.

4. Thompson AJ, Baranzini SE, Geurts J, Hemmer B, Ciccarelli O. Multiple sclerosis. Lancet. 2018;391(10130):1622-1636.

5. Ghafari S, Ahmadi F, Nabavi M, Memarian R. Effects of applying progressive muscle relaxation technique on depression, anxiety and stress of multiple sclerosis patients in Iran National MS Society. Research in Med. 2008;32(1):45-53.

6. Halper J, Holland NJ. Multiple sclerosis: a self-care guide to wellness: Demos medical publishing; 2005.

7. C GBD 2016 Multiple Sclerosis Collaborators. Global, regional, and national burden of multiple sclerosis 1990-2016: a systematic analysis for the Global Burden of Disease Study 2016. Lancet Neurol. 2019;18(3):269-285.

8. Azami M, YektaKooshali MH, Shohani M, Khorshidi A, Mahmudi L. Epidemiology of multiple sclerosis in Iran: A systematic review and meta-analysis, PLoS One. 2019;14(4).

9. José Sá M. Psychological aspects of multiple sclerosis. Clin Neurol Neurosurg. 2008;110(9):868-877.

10. Diaz-Olavarrieta C, Cummings JL, Velazquez J, Garcia de la Cadena C. Neuropsychiatric manifestations of multiple sclerosis. J Neuropsychiatry Clin Neurosci. 1999;11(1):51-57.

11. Brassington JC, Marsh NV. Neuropsychological aspects of multiple sclerosis. Neuropsychol Rev. 1998;8(2):43-77.

12. Landoni MG, Giordano MT, Guidetti GP. Group psychotherapy experiences for people with multiple sclerosis and psychological support for families. J Neurovirol. 2000;6 (2):168171.

13. Kluger BM, Krupp LB, Enoka RM. Fatigue and fatigability in neurologic illnesses: proposal for a unified taxonomy. Neurology. 2013;80(4):409-416.

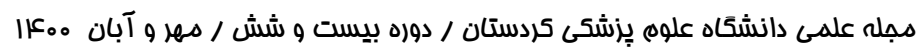


14. Penner IK, Paul F. Fatigue as a symptom or comorbidity of neurological diseases. Nat Rev Neurol. 2017;13(11):662-675.

15. Bagert B, Camplair P, Bourdette D .Cognitive dysfunction in multiple sclerosis: natural history, pathophysiology and management. CNS Drugs. 2002;16(7): 55-445.

16. Winningham ML, Nail LM, Burke MB, Brophy L, Cimprich B, Jones LS, et al. Fatigue and the cancer experience: the state of the knowledge. Oncol Nurs Forum. 1994;21(1):23-36.

17. Burfeind KG, Yadav V, Marks DL. Hypothalamic Dysfunction and Multiple Sclerosis: Implications for Fatigue and Weight Dysregulation. Curr Neurol Neurosci Rep. 2016;16(11):98.

18. Asadnia S, Mosarrezaii Aghdam A, Saadatmand S, Sepehrian Azar F, Torabzadeh, Naser. Examination the effectiveness of cognitive-behaviour therapy on improving depression and decreasing anxiety symptoms of multiple schorosis patient (MS). Studies in Med Scien 2015;25(11):32-1023.

19. Mohr DC, Hart SL, Goldberg A. Effects of treatment for depression on fatigue in multiple sclerosis. Psychosom Med. 2003;65(4):542-547.

20. Skerrett TN, Moss-Morris R. Fatigue and social impairment in multiple sclerosis: the role of patients' cognitive and behavioral responses to their symptoms. J Psychosom Res. 2006;61(5):587-593.

21. Hind D, Cotter J, Thake A, Bradburn M, Cooper C, Isaac C, et al. Cognitive behavioural therapy for the treatment of depression in people with multiple sclerosis: a systematic review and meta-analysis. BMC Psychiatry. 2014;14:5.

22. van Kessel K, Moss-Morris R, Willoughby E, Chalder T, Johnson MH, Robinson E. A randomized controlled trial of cognitive behavior therapy for multiple sclerosis fatigue. Psychosom Med. 2008;70(2):205-213.

23.Soleimani S, Tajoddini E. Effectiveness of cognitive behavioural therapy based on fatigue on dimension of mental fatigue in patient with multiple sclrosis: a case study. Journal of Clinic Psycho. 2016;8(2):13-21.

24. Pahlavanzadeh S, Dalvi-Isfahani F, Alimohammadi N, Chitsaz A. The effect of group psycho-education program on the burden of family caregivers with multiple sclerosis patients in Isfahan in 2013-2014. Iran J Nurs Midwifery Res. 2015;20(4):420-425.

25. Biglan A, Hayes SC, Pistorello J. Acceptance and commitment: implications for prevention science. Prev Sci. 2008;9(3):139-152.

26. Hayes SC, Luoma JB, Bond FW, Masuda A, Lillis J. Acceptance and commitment therapy: model, processes and outcomes. Behav Res Ther. 2006;44(1):1-25.

27.Parsa M, Sabahi P, Mohammadifar MA. The effectiveness of acceptance and commitment group therapy to improving the quality of life in patients with multiple sclerosis. Journal of Clinic Psycho. 2018;10 (1):8-21.

28.Roche L, Dawson DL, Moghaddam NG, Abey A, Gresswell DM. An Acceptance and Commitment Therapy (ACT) intervention for Chronic Fatigue Syndrome (CFS): A case series approach. Journal of Contexl Behavi Sci. 2017;6(2) 86-187.

29.Carrigan N, Dysch L. Acceptance and commitment therapy for the management of chronic neuropathic pain in multiple sclerosis: A case study. Neuro-disabil and Psychoth. 2015;3(2) 69-92.

30. Sturgeon JA. Psychological therapies for the management of chronic pain. Psychol Res Behav Manag. 2014;7:115-124. 
31. Davoodi M, Shameli L, Hadianfard H. The Effectiveness of Acceptance and Commitment Therapy on Chronic Fatigue Syndrome and Pain Perception in People With Multiple Sclerosis. IJPCP. 2019; 25 (3) :250-265.

32. Brassington L, Monteiro da Rocha Bravo Ferreira N, Yates S, Fearn J, Lanza P, Kemp K et al. Better living with illness: A transdiagnostic acceptance and commitment therapy group intervention for chronic physical illness. Journal of Contex Behavi Sci. 2016;5(4):208-214.

33. Burgess M, Andiappan M, Chalder T. Cognitive behaviour therapy for chronic fatigue syndrome in adults: face to face versus telephone treatment: a randomized controlled trial. Behav Cogn Psychother. 2012;40(2):175-191.

34. van den Akker LE, Beckerman H, Collette EH, Twisk JW, Bleijenberg G, Dekker J, et al. Cognitive behavioral therapy positively affects fatigue in patients with multiple sclerosis: Results of a randomized controlled trial. Mult Scler. 2017;23(11):1542-1553.

35. Moss-Morris R, Dennison L, Landau S, Yardley L, Silber E, Chalder T. A randomized controlled trial of cognitive behavioral therapy (CBT) for adjusting to multiple sclerosis (the saMS trial): does CBT work and for whom does it work?. J Consult Clin Psychol. 2013;81(2):251-262.

36. van Kessel K, Moss-Morris R. Understanding multiple sclerosis fatigue: a synthesis of biological and psychological factors. J Psychosom Res. 2006;61(5):583-585.

37. Veehof MM, Trompetter HR, Bohlmeijer ET, Schreurs KM. Acceptance- and mindfulness-based interventions for the treatment of chronic pain: a meta-analytic review. Cogn Behav Ther. 2016;45(1):5-31.

38. Phyo AZZ, Demaneuf T, De Livera AM, Jelinek GA, Brown CR, Marck CH, et al. The efficacy of psychological interventions for managing fatigue in people with multiple sclerosis: A systematic review and meta-analysis. Fronti in Neuro. 2018;9:149.

39. Pagnini F, Bosma CM, Phillips D, Langer E. Symptom changes in multiple sclerosis following psychological interventions: a systematic review. BMC Neurol. 2014;14:222.

40. Turk DC, Melzack R. Handbook of pain assessment: Guilford Press; 2011. 